\title{
The Influence of International Instruments on Public Service Labour Relations in Botswana Prior to the Advent of Unionization
}

\author{
K. Solo \\ University of Botswana, Gaborone, Botswana \\ Email: solok@ub.ac.bw
}

How to cite this paper: Solo, K. (2021). The Influence of International Instruments on Public Service Labour Relations in Botswana Prior to the Advent of Unionization. Beijing Law Review, 12, 177-190. https://doi.org/10.4236/blr.2021.121010

Received: January 21, 2021

Accepted: March 16, 2021

Published: March 19, 2021

Copyright $\odot 2021$ by author(s) and Scientific Research Publishing Inc. This work is licensed under the Creative Commons Attribution International License (CC BY 4.0).

http://creativecommons.org/licenses/by/4.0/

\section{(c) (i) Open Access}

\begin{abstract}
Freedom of Association is a fundamental human right. It is essential to sustained progress. There is security of employment in circumstances where an employee is allowed to join a union and within that union to bargain collectively with others. Initially in Botswana, public sector employees could not belong to unions. It was through the influence of international instruments that Botswana subsequently allowed public sector unions to unionise. This paper touches on the significant provisions of the International Labour Organisation that were instrumental in the change of mindset. International labour standards impact positively on security of tenure in both the public and private sector, especially Freedom of Association. The paper acknowledges the special and peculiar nature of the public service, but however urges for an indivisible labour law regime for both public and private employment according to historical and comparative materials perused.
\end{abstract}

\section{Keywords}

Security of Employment, International Conventions, International Labour Organization, Collective Bargaining, Right to Strike, Public Service and Unionization

\section{Introduction}

Freedom of association (from which the right to join a union and within that union to bargain collectively with others is derived) is a fundamental human right. According to the "Declaration of Philadelphia" in 1944 by the labour conference, it is essential to sustained progress. International instruments of the international labour organisation are the high water mark of international labour 
legislation. In this paper, there are the litmus papers against which international developments in countries who have ratified international labour instruments are measured against. To this end, Botswana labour legislation is measured and interpreted in terms of these international instruments.

Public service labour relations impact significantly on security of tenure of public servants. This paper underscores the contention that there is more security of employment in circumstances where an employee is allowed to join a union and within that union bargain collectively with others.

An attempt is made to find out how aspects of industrial relations in Botswana have significantly been influenced by conventions and recommendations of the International Labour Organisation. An argument is made that International labour standards impact positively on security of tenure in both the public and private sector, especially the right to freedom of association. The paper acknowledges the special and peculiar nature of the public service, but however urges for an indivisible labour law regime for both public and private employment.

The position in Botswana was less than satisfactory in that only associations were permitted and only manual workers employed by the state could organize and belong to unions. An outline of unionization in the public service in Botswana is made prior to the advent of public service trade unions.

\section{International Labour Organisation Standards}

International Labour Organisation standards are intended to be universal in nature (ILO, 1998). They are intended to be applicable to and capable of attainment by countries with very different social structures and at different stages of industrial development (ILO, 1998). They are flexible and set as meaningful targets for social development. In framing any conventions or recommendations the International Labour Organisation has "due regard to those countries in which climatic conditions, the imperfect development of industrial organization, or other special circumstances make the industrial conditions substantially different and shall suggest the modifications, if any, which it considers may be required to meet the case of such countries (ILO, 1998)." Systematic efforts are made in the standard setting process to give effect to this constitutional principle (ILO, 1998).

International labour standards have exerted and continue to exert their influence in every corner of the world, in industrialised and developing countries alike, that the policy constantly pursued by the International Labour Organisation of adopting standards designed to be universally applicable would appear to be still fully valid today (ILO, 1998).

\section{Recommendations}

International Labour Organisation standards may either take the form of a convention or recommendation. A convention is designed to be ratified. Like an international treaty, a ratifying state undertakes to discharge certain binding obli- 
gations, and there is regular international supervision of the way in which those obligations are observed (ILO, 1998). A recommendation on the other hand, gives rise to no binding obligations but provides guidelines for national policies and action. It is essentially for this reason that workers' delegates to the International Labour Conference often press for the adoption of conventions whereas the employers' delegates are more in favour of recommendations (ILO, 1998).

It is against this background that when we consider the question of unionization in the public service, particularly the right to join a union, the relevance of International Labour standards comes to the fore. The question then becomes, what do International Labour Organisation conventions and recommendations say on the matter?

The question of unionization, whether in the public or private sector is inextricably linked, if not part of the broader fundamental human right called freedom of association. Human rights are an essential concern of the International Labour Organisation, and none of them is more important to it than freedom of association (ILO, 1998). As a specialized agency within the United Nations system, the International Labour Organisation is an organization with the fundamental purpose of defending and increasing human freedom, and in particular civil liberties (ILO, 1998).

\subsection{Freedom of Association Conventions No. 87 and 98}

The International Labour Organisation has adopted several conventions relate freedom $d$ to freedom of association. Convention no 87 and 98 belong to the category of its instruments the purpose of which is to promote and guarantee certain basic human rights within the broader sphere of social rights (ILO, 1995). The principles embodied in these Conventions do not presuppose any standard pattern of trade union organization, but they serve as a yardstick against which to measure of a trade union movement, irrespective of the way in which it is organized (ILO, 1995).

Conventions no 87 and 98 cover different areas as regards the exercise of trade union rights and their provisions are intended primarily as safeguards to guarantee the exercise of these rights as appropriate to the area concerned (ILO, 1995). Both conventions protect the right to establish and join a trade union, but not freedom of non-association.

"In fact, during the discussion of the first of these instruments an amendment to secure recognition of the right not to join an organization was rejected. Subsequently, at the time of the adoption of Convention 98, it was agreed that this instrument should not be interpreted as authorizing or prohibiting union security arrangements, such questions being matters for regulation in accordance with national practice. In consequence, legal systems which permit the conclusion of union security clauses are not deemed to be contrary to convention 98 , nor are those which prohibit such practices in pursuance of the principle of freedom of non-association (ILO, 1995).” 
It should be borne in mind, that the fundamental inquiry here is the influence of international instruments on the then public service relations which did not allow unions. To the extent that this inquiry is being examined we are constrained to consider the question of unionization in the public service which is bound with the broader fundamental right of freedom of association. It will be argued in the course of the study that the extension of freedom of association to workers, either in the public or private sector greatly enhances and promotes security of employment. The following freedom of association principles taken from: International Labour Organisation Principles, Standards and Procedures Concerning Freedom of Association (ILO, 1995) underscore the importance and significance of the above contention.

Recognition of the right to organize: the right to organize is to be granted to workers and employers, without distinction whatsoever (Article 2 of Convention No. 87). Only the armed forces and the police may be exempted by national laws or regulations. The general right guarantees freedom of association without distinction or discrimination in respect of occupation, sex, colour, creed, race, nationality or political opinion. The supervisory bodies of the International Labour Organisation have clearly indicated that national legislation that seeks to deny or restrict the recognition of the right to organize of certain groups, whether established by occupation or by other criteria, contravenes the convention (ILO, 1995).

While the tenor of Convention no. 87 is crystal clear, and in conformity thereof, virtually all countries recognize the right of association of workers in the private sector in order to defend their rights by being organized, the same does not always apply to public servants and officials. There are those countries whose public servants have exactly the same right of association as their private sector counterparts; in others the right does not exist for certain classes of public servants or is curtailed by restrictions that do not normally apply to other workers. And in some countries, the legislation does not recognize the right of all public servants and officials to organize, or explicitly refuses them this right (ILO, 1995).

In Botswana a distinction was previously made between public servants who are manual workers and those who are not manual workers. Manual workers who are public servants were then accorded the right to form and belong to unions in order to defend their rights but the other class of public servants was allowed to set up associations which were in fact recognized by the government as the employer for the purpose of discussing wages and other aspects of working conditions. The fact that their right of association was recognized by law did not mean that as public employees they were able to establish effective organisations to protect their interests. Consequently, Botswana belonged to that category of countries where the right to form and belong to trade unions for certain classes of public servants did not exist or is curtailed by restrictions that do not normally apply to other workers. The lack of effective organization seriously compro- 
mises and erodes the ability of public servants to negotiate with their employer for a better and more secure employment relationship.

Although the armed forces and the police are the only classes that may be excluded under Convention no. 87 from the right to establish trade unions, the legislation in some countries also excludes fire service personnel and prison staff (the latter on the grounds that they are comparable to the police). So far as the International Labour Organisation is concerned, the functions exercised by these classes of public servants would not normally justify their exclusion from the right to organise under Article 9 of the Convention (ILO, 1995).

\subsection{Establishment of Organisations}

It must be possible for organisations to be established without previous authorization (Article 2). In terms of Article 2 workers and employers should not have to seek permission from the public authorities before setting up an industrial organization. Clearly and by implication, the authorities should not impose legal formalities which would be equivalent, in practice, to previous authorization nor constitute an obstacle amounting in fact to a prohibition (ILO, 1975).

Workers and employers are guaranteed the right to establish and, subject only to the rules of the organization concerned, to join organization of their own choosing (Article 2). This freedom of choice in establishing and joining organisations must be regarded as one of the foundations of freedom of association. It entails among other things, the right to determine the structure and composition of trade unions; to set up one or more organisations in any one enterprise, occupation or branch of activity, and to establish federations or confederations in full freedom (ILO, 1975).

The setting of a minimum number of members for an organization could well affect freedom of choice by making it more difficult to establish an organization. The principle to be applied in this regard is that where an effort is made to specify the minimum number of members for the founding or the existence of an organization, this number should be set at a reasonable level, so that the establishment of the organization should not be hindered (ILO, 1975).

\subsection{Functioning of Organization}

Organisations shall be free from interference by the public authority when drawing up their constitutions and rules, electing their representatives, organizing their administration and activities and formulating their programmes (Article 3). International Labour Organisation instruments seek to guarantee not only the right to establish and join organisations but also the freedom of these organisations to function.

\subsection{Federations and Confederations}

Organisations shall have the right to establish and join federations and confederations (Article 5). Freedom of Association Convention No. 87 encourages and 
gives trade unions organisations the freedom to join or establish federations and confederations so that they can effectively represent their workers. Employers also have a similar right to join and establish federations and confederations to articulate their interests.

\subsection{Anti-Union Discrimination}

Workers shall enjoy adequate protection against acts of anti-union discrimination in respect of their employment, both at the time of entering employment and during the employment relationship. Such protection shall apply more particularly in respect of acts calculated to:

1) Make the employment of a worker subject to the condition that he shall not join a union or shall relinquish trade union membership;

2) Cause the dismissal of or otherwise prejudice a worker by reason of union membership or because of participation in union activities outside working hours or, with the consent of the employer, within working hours (Article 1 of Convention 98).

Importance of convention 87 (1948) concerning freedom of association and protection of the right to organize and its impact on security of employment in the public service.

Freedom of Association is one of those fundamental human rights enunciated by the United Nations in December 1948 in the Universal Declaration of Human Rights. It is also in the International Covenant on Civil and Political Rights. Amongst those principles enunciated in the Universal Declaration of Human Rights which are of equal importance (some of which are pertinent to the present study) are:

1) The right to freedom and security of the person and freedom from arbitrary arrest and detention.

2) Freedom of opinion and expression and in particular freedom to hold opinions without interference and to seek and receive and impart information and ideas through any media and regardless of frontiers;

3) Freedom of assembly;

4) The right to a fair trial by an independent and impartial tribunal;

5) The right to protection of the property of trade union organisations.

The International Labour Organisation, owing its existence largely to the promotional efforts of trade union organisations, could not fail to give recognition in its constitution of 1919 to the principle of freedom of association as of one of the objectives to be attained by the Organisation through its programme of action (ILO, 1995). The "Declaration of Philadelphia" in 1944 by the Labour Conference re-affirmed this principle, it being emphasized that "freedom of expression and association" are essential to sustained progress. There is no doubt, that it was because of the continued importance of this principle that when most of the former British colonies in Africa gained their independence, they had freedom of assembly and association enshrined in their constitutions, and pro- 
tected as a fundamental right and freedom of the individual. The power of the workers irrespective of whether they were employed in the public service or in the private sector lay in their ability to freely associate and freely organize themselves into workers organisations or associations, and only then could they collectively through representatives of their own choice, articulate their interests and defend their rights. Consequently freedom of expression and association is the vehicle through which they can speak and be heard. Taking the argument to its logical conclusion, workers security of tenure is better protected through continued dialogue by workers representatives with their employers or employers organisations. As the old adage goes; "Unity is Strength". The strength of the workers lies in their unity. This then brings as to the International Labour Organisation principles, standards and procedures outlined above concerning freedom of association. The above outlined principles are so basic to ensuring security of employment in the public service that a denial to public servants of any one of them seriously compromises and threatens to erode the collective power that public servants potentially have either as associations or organisations or in whatever form they may exist.

\subsection{Collective Bargaining in the Public Service}

Convention no. 87 and Convention no. 98 protect the right to establish and join a trade union. The latter Convention is mainly concerned with the protection of trade unions and is also an International Labour Organisation instrument setting forth its basic principles in respect of collective bargaining, the obligation to promote this practice and the voluntary nature of such bargaining (ILO, 1995). The right to establish and join trade unions would itself be empty if there was no protected right to organise and bargain collectively. Consequently, collective bargaining is fundamental to the whole question of security of tenure. While Convention no. 98 is supposedly not meant to deal with the position of public servants engaged in the administration of the state nor was it to be construed as prejudicing their rights or status in any way, it is very relevant to the present enquiry. Its relevance lies in it being an accepted institution in all modern industrial societies to resolve disputes between employers and employees and to determine minimum wages and working conditions. While this paper vehemently agitates for collective bargaining structures to be extended to the public services to the maximum extent possible for purposes of employment security, it is however appreciated that the public service has special characteristics which are found in various degrees in most countries. For purposes of completeness it is important that we explore some of the arguments for treating public sector work differently from the private sector.

The following were some of the arguments identified in a paper entitled; "Collective bargaining in the Public Sector" at a conference on Labour Law.

i) Executive nature of service: according to the paper the exclusion of public sector employment collective bargaining is sometimes founded on the premise 
that the service is semi-political and vocational and that the purpose of government is not profit or self interest, but public interest. Functionaries in the public service are seen as a neutral subordinate component, at the call of the government of the day to execute policy and law. The author however contends that the above ground is anachronistic, that the service may be in the public interest although the employees who deliver the service may be motivated their own and not the public interest.

2) Collective bargaining jeopardises state security: on this score it is argued by the author that there is concern that if employees in government service have a right to associate this may clash with state security. For this reason even the International Labour Organisation Convention on Freedom of Association and the Right to Organise which guarantees workers the right to form and join organisations of their own choosing to all workers, permits exclusion of the armed forces and the police.

3) Public sector employment is quintessentially political: Collective bargaining and strikes in the private sector are in part justified precisely because they are private and the economic pressure of a dispute between an employer and its workforce is felt by the employer who controls the workplace and has the capacity as well as the legal or at least equitable obligation to negotiate a settlement. Secondary strikes involve employers who are not directly in dispute with the striking workers and are viewed less favourably and tend to receive little or no legal support.

Christie (1993) argues that in a sense all public sector strikes are secondary as the social and economic costs of public sector labour disputes are not carried by the state as employer, but by an unpredictable community. She gives the example that if clerical staff in the department of manpower were to strike, Workmen's Compensation Act benefits are denied to people who have nothing to do with the dispute and no direct or immediate capacity to effect change in attitude or behavior of those directly in conflict.

4) Public service tends to a monopoly: it is argued by the author, that public service is often a monopoly or near monopoly and this may make it difficult to set up a substantive service should labour disputes threaten service continuity. That furthermore, the consequences may be devastating to public health and security.

5) Public sector provides essential services: There is an assumption here that all public or government service is essential and that the focus of legislative control is directed at ensuring "the continuation of the service at a basic level, either by the workers in dispute or by others".

Christie in her paper argues that while some services may be essential there are inconsistencies. Some services she argues are essential and yet are unregulated. Others are deemed essential yet they are not. The Labour Relations Act outlaws all strikes in essential services. Discussing the notion that the public service is essential, the author says: 
"There is little factual support for the notion that public service is preternaturally essential. The functions and service of modern governments (and local authorities) vary in the degree to which they are essential to public welfare and attempts to define essential service are bedeviled by social and economic relativism. As state departments and agencies become privatized, the nature of the state as employer has changed. The service supplied by the military, the policy and fire fighters is different in importance and kind from that of the public service and teachers. We should explore the extent and nature of the public service and consider whether a particular service is monopolistic and the extent to which the state is involved in economic activities."

The above are some of the arguments generally put across to vitiate the contention that there should be collective bargaining in the public service. It may be quite difficult to refute some of the above arguments and International Labour Organisation recognizing this dilemma, allows some flexibility in the choice of methods of determining conditions of employment in the public service. Procedures enabling conditions of employment to be negotiated between public authorities and the organisations concerned are envisaged by the International Labour Organisation or such other methods as will allow representatives of public employees to participate in the determination of those matters. Article 6 of Convention 98 allows public servants engaged in the administration to be excluded from its scope (collective bargaining and the obligation to promote it) but other categories should enjoy the guarantees of the convention and therefore be able to negotiate collectively their conditions of employment, including wages (ILO, 1994). Countries like Argentina, Belgium, Guatemala, Italy, Spain and Portugal have legislation guaranteeing the right of collective bargaining of the public servants (ILO, 1994). It is however denied to public servants in Colombia, Iraq, Liberia and Pakistan amongst other countries.

It should be borne in mind that the focus of the present paper is the importance of unionization in the public service and how it impacts on security of employment therein. Amongst background material are the International Labour Organisation convention and recommendations of freedom of association and collective bargaining. There is absolutely no doubt that the essence of their existence is to greatly enhance the bargaining power of the workers. This is irrespective of where they are employed, semi-public or private employment. What follows is the position of unionization in the public service in Botswana.

\subsection{Unionization in the Public Service in Botswana}

In considering the issue of unionization in the public service in Botswana, the genesis is none other than the constitution of the country, of which the relevant section is 13(1), falling under protection of fundamental rights and freedoms of the individual. The section is reproduced below in its entirety. 
"13 (1) Except with his own consent, no person shall be hindered in the enjoyment of his freedom of assembly and association, that is to say, his right to assemble freely and associate with other persons and in particular to form or belong to trade unions or other associations for the protection of his interests.

2) Nothing contained in or done under the authority of any law shall be held to be inconsistent with or in contravention of this section to the extent that the law in question makes provision:

a) That is reasonably required in the interests of the defence, public safety, public order, public morality or public health;

b) That is reasonably required for the purpose of protecting the right of freedoms of other persons;

c) That imposes restrictions upon public officers, employees of local government bodies, or teachers; or

d) For the registration of trade unions and associations of trade unions in a register established by or under any law, and for imposing reasonable conditions relating to the requirements for entry on such a register (including conditions as to the minimum number of persons necessary to constitute a trade union qualified for registration) and conditions whereby registration may be refused on the grounds that any other trade union already registered, or association of trade unions already registered, as the case may be, is sufficiently representative of the whole or of a substantial proportion of the interests in respect of which registration of a trade union or association of trade unions is sought, and except so far as that provision or, as the case may be, the thing done under the authority thereof is shown not be reasonably justifiable in a democratic society (Constitution of Botswana, 1966)”.

The freedom to assemble and associate with other persons and in particular to form and belong to trade unions or other associations for the protection of ones interests is generally permitted by the constitution of Botswana. While the constitution allows restrictions to be imposed on public officers, employees of local government bodies or teachers in respect of forming or joining trade unions or other association, the present restrictions arise mainly by necessary implication. The Employment Act of Botswana which mainly regulates employment relationships between private and parastatal sector employees and employers allows public sector employees of the industrial class to form and belong to trade unions. The term "employee" in the Employment Act has been defined to include industrial class employees in the public sector. The industrial class employees apart, all categories of employees in the public sector were not allowed to form and belong to a trade union or to enter into collective bargaining or any meaningful negotiations about the terms and conditions of service with the employer, the government. The Public Service Act, which is concerned with the organization of the civil service, appointments and conditions of service, stipulated that the President may make regulations for the setting up of a body for the purpose 
of consultations between government and public sector employees (Public Service Act, 2008). The body that had been created to cater for such consultations in central government was the Botswana Civil Servants Association, and in local authorities was the Botswana Unified Local Government Service. Both bodies could only consult, and could not enter into any collective bargaining with government on behalf of their members. This conspicuous absence of collective bargaining or the denial thereof to public servants other than to the industrial class workers dealt a terrible blow to job security in the public service, and consequently rendered the so-called freedom of assembly and association enshrined in Section 13 of the constitution a hollow right for the majority of public servants. It is perhaps convenient at this stage to sketch an outline of the consultation process between central government and public servants.

\subsection{The Consultation Framework}

The public service consultative machinery had two levels. The lower level had been created at the ministerial level to deal mainly, but not exclusively, with ministry specific issues only. In this respect the relevant section provided (Public Service Act, 2008).

"1) There shall be established in each Ministry a Ministerial Consultative Committee which shall consist of the Permanent Secretary of the Ministry who shall be the Chairman and three other members in that Ministry who shall be appointed by the Minister of that Ministry, and four members (who may or may not be members of the association) appointed by the association or, in default of the appointment, elected from among themselves by persons employed in that Ministry.

2) In appointing the members the association shall bear in mind the need to represent as far as possible all categories of staff in such Ministry.

3) The members appointed by the association shall be appointed after the members appointed by the Minister and the association shall not appoint any person to be a member who has been so appointed by the Minister."

The other level was the Central Joint Staff Consultative Council. Ministerial Consultative Committees operating within each of the executive ministries reported to the Central Joint Staff Consultative Council, which was the national body nominated partly by the Minister responsible for the public service and partly by the Botswana Civil Servants Association. The section creating the Central Joint Staff Consultative Council provided:

"1) There shall be established a Central Joint Staff Consultative Council which shall consist of the Director and six other members of the rank of Permanent Secretary who shall be nominated by the Minister, and the Minister shall appoint one of those seven members to be Chairman, together with six members nominated by the Association.

2) In nominating the members, the Association shall bear in mind the need 
to represent as far as possible all categories of officers in the public service.

3) There shall be a Deputy Chairman of the Council elected from among themselves by the members nominated by the Association."

The Council was enjoined by the Regulations to, inter alia, consider terms and conditions of service and advise on methods of ensuring improvements in general working conditions, productivity and staff relations within the public service and on measures necessary for the furtherance of good industrial relations between government and the public service (2008).

The consultative machinery had been in existence for more than 18 years and was the result of the successful negotiation between the National Executive Committee of the Botswana Civil Servants Association and His Excellency the late President of the Republic of Botswana in February, 1970.

The Public Service Consultative Machinery was established to promote better industrial relations between public servants generally as employees, and, government as employer. This machinery enjoyed both the legal backing and the political commitment of the government. The crucial question was therefore whether the consultative machinery played the role that collective bargaining could have played in the public service employment relationship. Could the consultative machinery impact significantly on the security of employment of public servants? Could it improve and maintain desirable industrial relations between government and public servants? If the consultative machinery could impact on security of tenure of public servants, the extent to which it could do so was obviously less than what collective bargaining could do for public servants. It is conceded that the consultative machinery could indeed to some extent improve and maintain cordial relations between government and public servants, but not to the extent that forming and belonging to trade unions, and engaging in collective bargaining could have done for them. Consequently the consultative machinery though useful sharply compromised the ability of public servants to collectively engage their employer in the protection of their interests as workers. As a result of the consultative machinery, public servants could not engage in industrial action. Indeed there was no room for industrial action in the consultative machinery. There was no ultimate weapon that public servants (other than industrial workers) wielded in order to carry through their demands when negotiating with government. In the ultimate analysis, the consultative machinery legitimized governmental action and agenda.

The absence of the right to strike in the consultative machinery, which right should be seen as an essential part of the mechanism of collective bargaining through which capitalism tries to accommodate conflict between workers and employers, robs the process of what could otherwise have been a good association for public servants.

"These are the ultimate sanctions without which the bargaining powers of the two sides lack credibility. There can be equilibrium in industrial relations without freedom to strike (Freud, 1977)". 
"While this consultative arrangement is suitable for a highly developed system of negotiation and joint consultation, it has not been $100 \%$ successful. In practice and in reality there have been relatively fewer shortcomings than successes of this consultative machinery (Molosi, 1988)."

Examples (Molosi, 1988) of some of the shortcomings of this system of negotiation included the following:

1) Some ministerial consultative committees not functioning effectively due to a variety of reasons;

2) Submission of agenda items system not functioning as smoothly as desired both at ministerial and national levels;

3) Promotion of some influential and effective members representing public servants to higher posts having disruptive impact at the Central Joint Staff Consultative Council; and

4) Reluctance or indifference of the majority of public service employees to join the Botswana Civil Servants Association which has a negative impact on the strengthening of the Association and consequently the consultative machinery which was intended to benefit all civil servants.

\section{Main Findings}

The constitution of Botswana allows every individual freedom of association and of assembly in its fundamental rights and freedoms or bill of rights. This is no doubt in accordance with the Universal Declaration of Human Rights, International Covenant on Civil and Political Rights and the African Charter which Botswana has not ratified. What the constitution of Botswana gives with the right hand (freedom of association) it again took away with the left hand (places restrictions on that freedom). The result is therefore that legislation in Botswana did not allow all public servants to unionise and bargain collectively in order to protect their interests. Only a few public servants could do so and these are industrial workers in public employment.

\section{Conclusion}

The system of negotiation and joint consultation between public employees and government did not always function effectively. Even if it did, which is rare, public servants could not engage in industrial action, the ultimate power that private sector employees had at their disposal in solving their disputes. It is only when all public servants are allowed to unionise and bargain collectively with the threat of the use of strike action that there can be relative security of employment in the public service. It was therefore with hindsight that government relented and allowed public sector workers to form and belong to unions. The above is therefore the background against which public sector workers went through before they were allowed to form and belong to unions. The landscape has now changed in that they can now engage in industrial action. 


\section{Conflicts of Interest}

The author declares no conflicts of interest regarding the publication of this paper.

\section{References}

Christie, S. (1993). First Regional Workshop on Labour Law and Industrial Relations in a Changing Southern Africa.

Constitution of Botswana (1966). Cap 01:01.

Freud, K. (1977). Labour and the Law. London: Stephen and Sons.

ILO (1975). Freedom of Association: An International Survey. Geneva.

ILO (1994). Freedom of Association and Collective Bargaining International Labour Conference. Geneva.

ILO (1995). Principles, Standards and Procedures Concerning Freedom of Association. Geneva.

ILO (1998). International Labour Standards. A Workers Education Manual (2nd ed.). Geneva.

Molosi, P. (1988). Discussion Notes on the Botswana Public Service Consultative Machinery, Failures and Successes.

Public Service Act (2008). Cap 26:01. Laws of Botswana. 